\title{
Analysis of Physicochemical Parameters, Anions and Major Heavy Metals of the Dhaleshwari River Water, Tangail, Bangladesh
}

\author{
Md. Aminul Ahsan", Md. Abu Bakar Siddique ${ }^{1, ~ *, ~ M a h b u b a ~ A k h t e r ~ M u n n i ², ~ M d . ~ A h e d u l ~ A k b o r ~}{ }^{1}$, \\ Shakila Akter ${ }^{1}$, Md. Younus Mia ${ }^{2}$ \\ ${ }^{1}$ Institute of National Analytical Research and Service (INARS), Bangladesh Council of Scientific and Industrial Research (BCSIR), Dhaka, \\ Bangladesh \\ ${ }^{2}$ Department of Environmental Science and Resource Management, Mawlana Bhashani Science and Technology University, Tangail, \\ Bangladesh
}

Email address:

sagor.bcsir@gmail.com (Md. A. B. Siddique)

To cite this article:

Md. Aminul Ahsan, Md. Abu Bakar Siddique, Mahbuba Akhter Munni, Md. Ahedul Akbor, Shakila Akter, Md. Younus Mia. Analysis of Physicochemical Parameters, Anions and Major Heavy Metals of the Dhaleshwari River Water, Tangail, Bangladesh. American Journal of Environmental Protection. Vol. 7, No. 2, 2018, pp. 29-39. doi: 10.11648/j.ajep.20180702.12

Received: July 19, 2018; Accepted: July 30, 2018; Published: August 22, 2018

\begin{abstract}
Dhaleshwari is one of the most important rivers in Bangladesh and plays a vital role in the economy of the Tangail region of Bangladesh due to its geographical position. However, anthropogenic activities are gradually degrading the aquatic system of the river. The present study was conducted at the three selected locations of the Dhaleswari river during March to May 2016 for physicochemical parameters: color, odor, temperature, $\mathrm{pH}, \mathrm{DO}, \mathrm{BOD}, \mathrm{EC}$, TDS; anions: $\mathrm{F}^{-}, \mathrm{Cl}^{-}, \mathrm{Br}^{-}, \mathrm{NO}_{3}^{-}, \mathrm{NO}_{2}^{-}$, $\mathrm{SO}_{4}{ }^{2-}$ and $\mathrm{PO}_{4}{ }^{3-}$ and major heavy metals: $\mathrm{Pb}, \mathrm{Cd}, \mathrm{Cr}, \mathrm{Hg}$ and $\mathrm{As}$ in order to estimate the current water pollution profile of the river. The color of water were natural to slightly green and odor were unobjectionable. Other measured physicochemical parameters ranged as temperature $29.3-32^{\circ} \mathrm{C}, \mathrm{pH} 6.78-8.12$, DO $4.11-7.31 \mathrm{mgL}^{-1}$, BOD 0.52-1.74 mgL ${ }^{-1}$, EC $127-487 \mu \mathrm{Scm}^{-1}$ and TDS 60-235 mgL ${ }^{-1}$. The anions concentration found as $\mathrm{F}^{-}<0.5, \mathrm{Cl}^{-} 1.08-6.8, \mathrm{Br}^{-}<1.0, \mathrm{NO}_{3}^{-} 0.51-19.7, \mathrm{NO}_{2}^{-}<1.0, \mathrm{SO}_{4}{ }^{2-}$ 3.34-9.37 and $\mathrm{PO}_{4}^{3-}$ 1.74-4.44 $\mathrm{mgL}^{-1}$. The concentration of major heavy metals obtained as $\mathrm{Pb}<0.01, \mathrm{Cd}<0.001, \mathrm{Cr}<0.005$, $\mathrm{Hg}<0.001$ and As $0.002-0.015 \mathrm{mgL}^{-1}$. The analysis of most of the water quality parameters were performed using standard methods of American Public Health Association. According to statistical analysis, temperature, EC and TDS show positive correlations with each other and negative correlations with $\mathrm{pH}, \mathrm{DO}$ and $\mathrm{BOD}$ which themselves show negative correlations with each other. The anionic pairs $\mathrm{Cl}^{-}-\mathrm{PO}_{4}{ }_{4}^{3-}, \mathrm{NO}_{3}{ }^{-}-\mathrm{SO}_{4}{ }^{2-}$, and $\mathrm{SO}_{4}{ }^{2-}-\mathrm{PO}_{4}{ }^{3-}$ show positive correlations and $\mathrm{Cl}^{-}-\mathrm{NO}_{3}^{-}, \mathrm{Cl}^{-}-\mathrm{SO}_{4}{ }^{2-}$ and $\mathrm{NO}_{3}{ }^{-}-\mathrm{PO}_{4}{ }^{3-}$ show negative correlations with each other. The analysis results of water body in regard to the studied water quality parameters revealed that the quality of water in the selected regions of the Dhaleshwari river is almost suitable for fishing, domestic and irrigation purposes. The water is safe for aquatic biota and human beings and also for industrial use without further treatment. Although adequate measure and treatment should be carried out in the water body for microbial contaminations before using for human consumptions.
\end{abstract}

Keywords: Dhaleshwari River, Physicochemical Parameters, Anions and Heavy Metals, Water Quality, Statistical Analysis, Aquatic Environment

\section{Introduction}

Degradation of water quality is one of the most serious environmental concerns today. Diffusion of various toxic pollutants into water exerts a great impact not only to the water body itself but also to the other ecosystems. This may affect the living organisms of the aquatic environment and the aquatic food chain may be bio-accumulated due to harmful substances in the water system. Due to the use of agrochemicals in the surrounding lands, industrial operation and any alterations in the river flow due to seasonal variation 
changes the inland surface water quality [1]. Bangladesh is a riverine country having approximately 230 large and small rivers. These rivers are large reservoirs of a wide variety of fish species and other aquatic resources [2]. The river water is used vastly for irrigation, electricity generation, navigation, recreation and many industrial and domestic purposes [3]. However, the excessive use of various agrochemicals in the nearby lands of the rivers, uncontrolled urbanization, lack of well planned development on the river banks, rapid industrialization and population growth are increasingly polluted the rivers of Bangladesh.

The Dhaleshwari river is an important distributary of the Jamuna river with a total length of about $290 \mathrm{~km}$ having average depth $37.19 \mathrm{~m}$ and maximum depth $80.79 \mathrm{~m}$ respectively which takes off in the northwestern part of Tangail district [4]. The surrounding lands are used for agricultural activities and water of this river is generally used for irrigation purposes. It supports the habitat for aquatic organisms including a wide variety of fishes and the aquatic vegetations in the river bank. The used insecticides, pesticides and fertilizers in the surrounding cultivated lands are frequently polluting the river by washing out through surface runoff mostly in rainy seasons [5]. Peoples nearby the river use its water for washing their cloths, bathing, washing their cattle etc. These anthropogenic activities may degrade the quality of water of Dhaleshwari river.

Islam et al. [5] studied the water quality in the Dhaleshwari river during the period from June 2011 to May 2012 in monsoon, post-monsoon and pre-monsoon seasons. The results of the study with respect to electrical conductivity, dissolved oxygen, biological oxygen demand, hardness, sodium, potassium, copper, cadmium, $\mathrm{pH}$, transparency, total dissolved solids, total nitrogen and phosphorus showed that level of most of the water quality parameters of the Dhaleshwari river were suitable for aquaculture of aquatic organisms as well as fishes. Real et al. [6] conducted the study for some physicochemical parameters $(\mathrm{pH}, \mathrm{BOD}, \mathrm{DO}$ and water temperature), anions $\left(\mathrm{PO}_{4}{ }^{3-}, \mathrm{SO}_{4}{ }^{2-}\right.$ and $\left.\mathrm{NO}_{3}{ }^{-}\right)$and some selected microorganisms consisted of total coliform, fecal coliform (Escherichia coli) and Vibrio cholera in the Dhaleshwari river during the period from April to June 2015 and found significant level of microbial pollution in Dhaleshwari river concluding that the water of Dhaleshwari river is polluted with organic and chemical pollutants and unhygienic for drinking and even unsuitable for domestic purposes and other human activities without proper treatment. However, they didn't study very much about the heavy metals and anions concentrations which also plays a vital role in assessing the water quality along with physicochemical and bacteriological (microorganisms) parameters.

The present study was conducted to assess the water quality of the river with respect to physicochemical parameters, anions and major heavy metals concentrations and to compare the findings with the surface water quality standards for Bangladesh.

\section{Materials and Methods}

\subsection{Sampling Site}

The selected Dhaleshwari river starts off the Jamuna river near the north-western tip of Tangail district and then divided into two branches: the name Dhaleshwari retains in the northern branch which merges at the southern part of Manikgang district with the other branch of Kaligonga river. The merged flow then meets at the Shitalakshya river near of Narayanganj district. This combined flow finally merge into the Meghna river moving southwards [4]. For the study, the three locations of the river were selected namely Porabari (Location 1), Katuli (Location 2) and Mahmudnagar (Location 3) union at Tangail sadar upazilla of Tangail district, Bangladesh (Figure 1). The three sampling locations with their latitude and longitude is shown in Table 1. The exact location of each sampling point was determined using global positioning system (GPS). The three selected sampling sites has no significant pollution sources except some agricultural lands and were selected as a part of regular study. The almost whole of the lands surrounding the three sampling points is mainly notable for the cultivation of some crops such as rice, jut, wheat, corn, mustard etc.



Figure 1. Map showing the three sampling sites (Study Area) of the Dhaleshwari river, Tangail, Bangladesh [7]. 
Table 1. Sampling location with latitude and longitude.

\begin{tabular}{llll}
\hline Station No. & Sampling Site & Latitude & Longitude \\
\hline Location 1 & Porabari & $24^{\circ} 43^{\prime} 333 \mathrm{~N}$ & $89^{\circ} 81^{\prime} 667 \mathrm{E}$ \\
Location 2 & Katuli & $24^{\circ} 08^{\prime} 553 \mathrm{~N}$ & $89^{\circ} 93^{\prime} 385 \mathrm{E}$ \\
Location 3 & Mahmudnagar & $24^{\circ} 03^{\prime} 088 \mathrm{~N}$ & $89^{\circ} 89^{\prime} 364 \mathrm{E}$ \\
\hline
\end{tabular}

\subsection{Sample Collection}

The climate of Tangail district is characterized by four seasons over the year: the summer monsoon (June to September), the retreating monsoon (October to November), the winter season (December to February) and the unsettled period of pre-summer monsoon (March to May). The maximum and minimum annual average temperature of Tangail district is $38.33^{\circ} \mathrm{C}$ and $10.13^{\circ} \mathrm{C}$ respectively with the annual rainfall of $1830 \mathrm{~mm}$ [8]. For the study, water samples were collected in the morning between $8.00-10.00 \mathrm{am}$, three times in each of the three months: March, April and May, 2016 after ten days interval from the three selected locations Porabari (Location 1), Katuli (Location 2) and Mahmudnagar (Location 3) area of the Dhaleshwari river in $1000 \mathrm{~mL}$ non-transparent plastic bottles. According to Brammer [9] samples collected during the month of March, April and May 2016 were fall in pre-monsoon (having high temperature and high evaporation rates) season with moderate intensity of rainfall compared to monsoon season (high intensity of rainfall).

Before sampling, the bottles were cleaned with detergent and then treated with $10 \%(\mathrm{v} / \mathrm{v})$ nitric acid $\left(\mathrm{HNO}_{3}\right)$ solution overnight. Then they were washed several times with deionized water until free from acid and dried in the air. During sampling, the bottles were washed at least three times with sampling water and then samples were taken with sealed immediately to avoid exposure to air and labeled properly. The samples were collected manually from about 2-3 $\mathrm{m}$ far from the bank of the river and about $1 \mathrm{~m}$ depth of the water surface avoiding scum with proper stirring of sampling point water following the sampling techniques described by American Public Health Association (APHA) [10] and fully filled in the plastic bottles such that no air can trap in the top of the bottles. The samples collected for heavy metal analysis were acidified immediately with $2 \mathrm{~mL}$ of concentrated $\mathrm{HNO}_{3}$ per liter of water to prevent the loss of metals by precipitation, absorption and/or ion exchange with the walls of the sample containers while for the purpose of analysis of other parameters, samples were collected without acidification. All the collected samples were then brought to the laboratory with care by ice carrier and preserved in the refrigerator at $4^{\circ} \mathrm{C}$ for the analysis in the laboratory [3].

\subsection{Sample Analysis}

The water samples were analyzed at ISO/IEC 17025 accredited laboratory of Institute of National Analytical Research and Service (INARS), Bangladesh Council of Scientific and Industrial Research (BCSIR), Dhaka, Bangladesh. The analyzed physicochemical parameters includes: color, odor, temperature, $\mathrm{pH}$, dissolved oxygen (DO), biological oxygen demand (BOD), electrical conductivity (EC), total dissolved solids (TDS), anions: fluoride $\left(\mathrm{F}^{-}\right)$, chloride $\left(\mathrm{Cl}^{-}\right)$, bromide $\left(\mathrm{Br}^{-}\right)$, nitrite $\left(\mathrm{NO}_{2}^{-}\right)$, nitrate $\left(\mathrm{NO}_{3}{ }^{-}\right)$, sulphate $\left(\mathrm{SO}_{4}{ }^{2-}\right)$ and phosphate $\left(\mathrm{PO}_{4}{ }^{3-}\right)$, and heavy metals viz. lead $(\mathrm{Pb})$, cadmium $(\mathrm{Cd})$, chromium $(\mathrm{Cr})$, mercury $(\mathrm{Hg})$ and arsenic (As). Almost all the parameters were analyzed using standard methods described by APHA [11]. Prior to analysis, all preserved samples were taken to the room temperature and water samples were preconcentrated for anions and heavy metals analysis. For all locations, three consecutive samples were collected, analyzed and finally their average value were taken. During analysis, accuracy and precision were verified by using reference materials from Fluka Analytical, Sigma-Aldrich. For analytical quality control, standard solution after five samples and a reagent method blank after ten samples were determined. In the analysis, spike recovery for all anions and heavy metals were $90-110 \%$ and calculated by the following equation.

$$
\operatorname{Recovery}(\%)=\frac{(\mathrm{a}-\mathrm{b}) * 100}{\mathrm{c}}
$$

Where, ' $a$ ' is the concentration of spike sample, ' $b$ ' is the concentration of unspike sample and 'c', the amount of spike.

All reagents were analytical grade (AR) and purchased from Merck, Germany. A calibrated electrical balance (GR200, A\&D Company Limited, Tokyo, Japan) with high precession was used for weighing purpose. Calibrated glass wars including pipette and volumetric flask were used for sample preparations. They were soaked in $10 \%$ (v/v) $\mathrm{HNO}_{3}$ overnight and rinsed with deionized water and dried prior using. The electrical conductivity and resistance of the frequently used deionized water throughout the whole experiment were approximately $0.2 \mu \mathrm{Scm}^{-1}$ and $18.2 \mathrm{M} \Omega-\mathrm{cm}$ respectively and prepared by RF ultrapure water system, Barnstead.

\subsubsection{Analysis of Physicochemical Parameters in Water}

Water color was observed by naked eyes and odor was felt with nose. The water temperature was recorded using a calibrated thermometer at the collection spots. DO, $\mathrm{pH}$ and EC of all water samples, were also measured at the collection spots and for their analysis, a portable Multiparameter meter (Model: sension ${ }^{T M} 156$, HACH) was used which was calibrated using traceable standards and measured instantly. A $100 \mathrm{~mL}$ of water sample was taken in a beaker and the electrode of the meter was immersed into the sample. By changing the machine command, the $\mathrm{DO}, \mathrm{pH}$ and $\mathrm{EC}$ were measured one by one and the process was followed for each water sample. TDS were measured manually or gravimetrically as the river water may contain some organic matter which does not completely ionized in water to be detectable by the Multiparameter meter. For the $\mathrm{BOD}_{5}$ analysis, DO of water samples were measured two times. At first day, DO values of water samples were measured and then the flasks filled with water sample were kept in an incubator at $20 \pm 2^{\circ} \mathrm{C}$. After 5 days the flasks were taken out 
from incubator to bring at room temperature and the DO levels were measured again carefully. Then the difference between the present and the previous DO values were calculated to get the $\mathrm{BOD}_{5}$ for each sample.

\subsubsection{Analysis of Anions in Water by Ion Chromatograph}

\section{i. Sample Preparation}

At first, the samples were filtered with Whatman ${ }^{\mathrm{TM}}$ qualitative 1 filter paper (125 mm dia.*100 circles) in order to remove sediment and other particulate matter and collected in $25 \mathrm{~mL}$ volumetric flask. Then the filtered samples were taken in sample vials by using syringe with 40 micron filter. Every times, the volumetric flasks, syringes and sample vials were washed with deionized water and rinsed at least three times with the respective samples.

\section{ii. Instrumental Analysis}

The prepared samples were analyzed by Ion Chromatograph (Model: $10 \mathrm{AD}$, SHIMADZU, Japan) for anions viz. $\mathrm{F}^{-}, \mathrm{Cl}^{-}, \mathrm{Br}^{-}, \mathrm{NO}_{2}^{-}, \mathrm{NO}_{3}{ }^{-}$and $\mathrm{SO}_{4}{ }^{2-}$. This is basically a separation technique and measures the concentration of anions in the samples based on their retention time and peak area as well as peak height of the chromatogram. A mixed standard solution of anions prepared from certified reference material (CRM) obtained from Fluka Analytical, SigmaAldrich was used as working standard for calibration purposes. The method detection limit (MDL) for $\mathrm{F}^{-}, \mathrm{Cl}^{-}, \mathrm{Br}^{-}$, $\mathrm{NO}_{2}{ }^{-}, \mathrm{NO}_{3}{ }^{-}$and $\mathrm{SO}_{4}{ }^{2-}$ ions were $0.03,0.17,0.10,0.05,0.10$ and $0.10 \mathrm{mgL}^{-1}$ respectively.

For the analysis of $\mathrm{PO}_{4}{ }^{3-}$ ion, UV-Visible Spectrophotometer (Model: UV-1650PC, SHIMADZU, Japan) was used. At first, $25 \mathrm{~mL}$ of water samples were taken in a $50 \mathrm{~mL}$ volumetric flasks and $10 \mathrm{~mL}$ venadate-molybdate reagent was added to it and diluted up to the mark with deionized water. Instrument baseline was constructed using deionized water. A calibration curve was prepared by running different concentrations of working standard solutions prepared from CRM (Fluka Analytical, Sigma-Aldrich) and concentration of unknown samples were determined against the prepared calibration curve. The sample solutions were transferred into cleaned quartz cell and placed in the path of light source of UV-Visible Spectrophotometer to start analysis which gives the concentrations of the sample as phosphorus determined against the calibration curve. The detection limit was $0.04 \mathrm{mgL}^{-1}$. From phosphorus concentration, phosphate ion concentrations in samples were calculated as follows:

Phosphate ion concentration, $\mathrm{mgL}^{-1}=\mathrm{A} \times \mathrm{F} \times 95 / 31$

Where, $\mathrm{A}=$ concentration of phosphorus in $\mathrm{mLL}^{-1}$ and $\mathrm{F}=$ dilution factor.

\subsubsection{Analysis of Heavy Metals in Water Samples by Atomic Absorption Spectrometer (AAS)}

\section{i. Sample Preparation}

At first, $100 \mathrm{~mL}$ of each water sample was taken in a 250
$\mathrm{mL}$ cleaned glass beaker by using a calibrated pipette and acidified with about 4-5 mL of concentrated $\mathrm{HNO}_{3}$. The beaker containing the sample was then heated on a hot plate at about $150-180^{\circ} \mathrm{C}$ for digestion and volume reduction to about 25-30 mL. After proper digestion, the cooled sample was taken in a $100 \mathrm{~mL}$ cleaned and calibrated volumetric flask rinsing the beaker several times with deionized water and finally, the flask was made up to the mark. Then, it was filtered with a Whatman ${ }^{\mathrm{TM}}$ qualitative 1 filter paper and preserved in a previously cleaned and dried $250 \mathrm{~mL}$ nontransparent plastic bottle with a label for the determination of heavy metals concentration. A sample blank was also prepared for quality control.

\section{ii. Instrumental Analysis}

Heavy metals in the prepared water samples were analyzed by AAS. The $\mathrm{Pb}, \mathrm{Cd}$ and $\mathrm{Cr}$ concentrations of the water samples were analyzed using Zeeman Atomic Absorption Spectrometer (Model: GTA 120-AA240Z with PSD 120 auto sampler, Varian, Australia). Hg concentration of the samples were analyzed using cold vapor hydride generation technique in AAS (Model: AA240 FS with VGA-77, Varian, Australia) and the concentration of Arsenic in the samples were determined using electric hydride vapor generation technique in AAS (Model: SpcetrAA 220 with an electrothermal temperature controller (ETC)-60 and VGA-77, Varian, Australia). The instrument uses specific hollow cathode lamp (HCL) for each metal under the conditions as shown in Table 2.

Table 2. HCL condition during heavy metal analysis by AAS.

\begin{tabular}{llll}
\hline Heavy & \multicolumn{3}{l}{ Hollow Cathode Lamp (HCL) Condition } \\
\cline { 2 - 4 } Metals & Lamp Current (mA) & Wavelength (nm) & Slit Width (nm) \\
\hline $\mathrm{Pb}$ & 10.0 & 217.0 & 1.0 \\
$\mathrm{Cd}$ & 4.0 & 228.8 & 0.5 \\
$\mathrm{Cr}$ & 7.0 & 357.9 & 0.2 \\
$\mathrm{Hg}$ & 4.0 & 253.7 & 0.5 \\
$\mathrm{As}$ & 10.0 & 193.7 & 0.5 \\
\hline
\end{tabular}

A calibration curve was prepared for all metals by running different concentrations of working standard solutions prepared from CRM (Fluka Analytical, SigmaAldrich) and concentrations of heavy metals of the samples were determined against the prepared calibration curve. Average values of three consecutive replicates were taken for each determination. The MDL for heavy metals: $\mathrm{Pb}, \mathrm{Cd}$, $\mathrm{Cr}, \mathrm{Hg}$ and As were 4.3411, 0.1986, 1.7963, 0.8071 and $0.0799 \mu \mathrm{gL}^{-1}$ respectively.

All stock standard solutions of physicochemical parameters, anions and heavy metals were $1000 \pm 4 \mathrm{mgL}^{-1}$ as traceable to National institute of Standards and Technology (NIST) and measured against CRM produced and certified in accordance with ISO/IEC 17025 and ISO guide 34.

\subsection{Statistical Analysis}

All statistical analyses were performed using IBM SPSS Statistics, version 20 (IBM Corporation, Armonk, NY). Descriptive statistics of the parameters were computed to 
show their average behaviors and dispersions. Pearson's computed to show the association among the parameters. correlation (r) matrix among the parameters were also

Table 3. Mean values of physicochemical parameters of water samples at three selected locations of the Dhaleshwari river during March to May, 2016 with measurement uncertainty $( \pm)(k=2)$.

\begin{tabular}{|c|c|c|c|c|c|c|c|}
\hline Locations & Months & Temperature $\left({ }^{\circ} \mathrm{C}\right)$ & pH & DO $\left(\mathrm{mgL}^{-1}\right)$ & $\mathrm{BOD}_{5}\left(\mathrm{mgL}^{-1}\right)$ & $\mathrm{EC}\left(\mu \mathrm{Scm}^{-1}\right)$ & TDS $\left(\mathrm{mgL}^{-1}\right)$ \\
\hline \multirow{3}{*}{$\begin{array}{l}\text { Porabari } \\
\text { (Location 1) }\end{array}$} & March & $31.7 \pm 0.06$ & $7.29 \pm 0.20$ & $5.73 \pm 0.97$ & $0.71 \pm 0.12$ & $362 \pm 2.90$ & $174 \pm 48.90$ \\
\hline & April & $30.0 \pm 0.06$ & $8.12 \pm 0.23$ & $4.99 \pm 0.85$ & $0.55 \pm 0.09$ & $310 \pm 2.48$ & $157 \pm 44.12$ \\
\hline & May & $29.3 \pm 0.06$ & $8.05 \pm 0.23$ & $6.32 \pm 1.07$ & $0.65 \pm 0.11$ & $318 \pm 2.54$ & $153 \pm 42.99$ \\
\hline \multirow{2}{*}{$\begin{array}{l}\text { Katuli } \\
\text { (Location 2) }\end{array}$} & April & $30.0 \pm 0.06$ & $7.72 \pm 0.22$ & $4.11 \pm 0.70$ & $1.74 \pm 0.30$ & $339 \pm 2.71$ & $165 \pm 46.37$ \\
\hline & May & $29.7 \pm 0.06$ & $6.78 \pm 0.19$ & $7.31 \pm 1.24$ & $1.74 \pm 0.30$ & $127 \pm 1.02$ & $60.0 \pm 16.86$ \\
\hline \multirow{2}{*}{$\begin{array}{l}\text { Mahmudnagar } \\
\text { (Location 3) }\end{array}$} & March & $31.0 \pm 0.06$ & $7.29 \pm 0.20$ & $5.54 \pm 0.94$ & $1.09 \pm 0.19$ & $487 \pm 3.90$ & $235 \pm 66.04$ \\
\hline & May & $30.0 \pm 0.06$ & $8.06 \pm 0.23$ & $6.47 \pm 1.10$ & $0.52 \pm 0.09$ & $127 \pm 1.02$ & $60.0 \pm 16.86$ \\
\hline \multirow{3}{*}{ Standard value } & BSTI & - & $6.4-7.4$ & Max. 6 & 6.0 & 3000 & Max. 500 \\
\hline & WHO & - & $6.0-8.5$ & Max.(4-6) & 5.0 & 3000 & Max. 500 \\
\hline & ECR & $20-30$ & $6.5-8.5$ & 6 & 0.2 & 3000 & 1000 \\
\hline
\end{tabular}

BSTI $=$ Bangladesh Standards and Testing Institute, $\mathrm{WHO}=$ World Health Organization, ECR $=$ Environment Conservation Rules

\section{Results and Discussion}

\subsection{Physicochemical Parameters}

The physicochemical parameters of the Dhaleswari river during the month March to May 2016 were measured as shown in Table 3. During the study period in Porabari site, color of water samples was almost natural and there was no bad smell in water. In Katuli, water had grey color and fishy odor and in Mahmudnagar site, water color ranged from light green to deep green which indicates the presence of high range of phytoplankton. Descriptive statistics and Pearson's correlation matrix of physicochemical parameters for the Dhaleswari river water are shown in Table 4 and 5 respectively. Most of the parameters shows significant correlations with each other which means that one parameter can predict the significance of the other [12].

Table 4. Descriptive statistics of the physicochemical parameters of water samples of the Dhaleswari river.

\begin{tabular}{llllllll}
\hline Parameters & N & Range & Min. & Max. & Sum & Mean & SD \\
\hline Temperature & 9 & 2.70 & 29.3 & 32.0 & 275.4 & 30.600 & 1.00747 \\
pH & 9 & 1.34 & 6.78 & 8.12 & 68.42 & 7.6022 & 0.45121 \\
DO & 9 & 3.20 & 4.11 & 7.31 & 50.32 & 5.5911 & 0.98686 \\
BOD & 9 & 1.22 & 0.52 & 1.74 & 8.880 & 0.9867 & 0.47133 \\
EC & 9 & 360 & 127 & 487 & 2690 & 298.89 & 115.338 \\
TDS & 9 & 175 & 60.0 & 235 & 1295 & 143.89 & 56.7110 \\
\hline
\end{tabular}

${ }^{* *}$ Min. $=$ Minimum, Max. $=$ Maximum, $\mathrm{SD}=$ Standard Deviation

Table 5. Pearson's Correlation matrix among the physicochemical parameters of water samples of the Dhaleswari river.

\begin{tabular}{lllllll}
\hline Parameters & Temperature & pH & DO & BOD & EC \\
\hline Temperature & 1 & -0.313 & -0.423 & -0.149 & 0.420 \\
pH & -0.313 & 1 & -0.300 & -0.600 & -0.039 \\
DO & -0.423 & -0.300 & 1 & -0.041 & -0.586 \\
BOD & -0.149 & -0.600 & -0.041 & 1 & -0.097 \\
EC & 0.420 & -0.039 & -0.586 & -0.097 & -0.021 \\
TDS & 0.385 & -0.021 & -0.590 & -0.108 & -0.108 & 0.99 \\
\hline
\end{tabular}

**. Correlation is significant at the 0.01 level (2-tailed).

\subsubsection{Temperature}

Temperature of water plays a vital role to assess the environment of water. Hot water contains less oxygen as cold water [13] which is harmful for aquatic life. An effective change in water temperature is dangerous for aquatic fish [14] and other phytoplankton. The temperature of the Dhaleswari river water were varied from 29.3 to $32^{\circ} \mathrm{C}$ as shown in Table 3 and shows insignificant negative correlations $(\mathrm{p}<0.01)$ with $\mathrm{pH}, \mathrm{DO}$ and BOD as $\mathrm{r}=-0.313$, $\mathrm{r}$ $=-0.423$ and $\mathrm{r}=-0.149$ and insignificant positive correlations with EC and TDS as $\mathrm{r}=0.420$ and $\mathrm{r}=0.385$. The $\mathrm{pH}$ and DO of water decreases with increasing temperature while EC increases due to the increased dissociation of the ionic substance.



Figure 2. Temp. with three months and locations. 


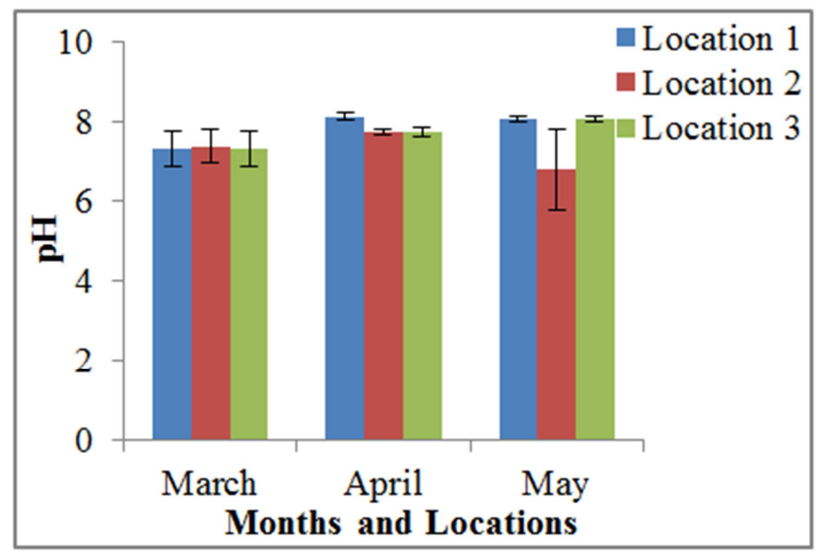

Figure 3. $p H$ with three months and locations.

The highest value of temperature was recorded at Location 2 (Katuli) in March and the lowest value was recorded at Location 1 (Porabari) in May. Values were comparatively high in Location 1 (Porabari) and Location 2 (Katuli) in the month of March and in Location 3 (Mahmudnagar) in April than other values. The temperature of Dhaleshwari river water varies with seasons and time in the year. The temperature in the post monsoon was recorded lower than that in the monsoon and pre-monsoon season which varies within the standard limit [5]. Islam et al. [15] recorded that the temperature of the Shitalakkhya river varied from 20.5 to $31.3^{\circ} \mathrm{C}$. Real et al. [6] found the temperature ranged between $29.5^{\circ} \mathrm{C}$ to $31.7^{\circ} \mathrm{C}$ at different stations in Dhaleshwari river during the period from April to June 2015 with mean value $29.9^{\circ} \mathrm{C} \pm 0.1^{\circ} \mathrm{C}, 31.17^{\circ} \mathrm{C} \pm 0.47^{\circ} \mathrm{C}, 29.5 \pm 0.06^{\circ} \mathrm{C}$ in April, May and June respectively.

\subsection{2. $\mathrm{pH}$}

$\mathrm{pH}$ of water indicates the nature of water whether it is acidic, basic or neutral. It controls the biological environment of water area. A drastic increase or decrease in $\mathrm{pH}$ level of water body exerts a fatal impact on aquatic life. Table 3 shows that the $\mathrm{pH}$ values varied between 7.29 and 8.12 and shows insignificant negative correlations $(p<0.01)$ with temperature, DO, EC and TDS as $r=-0.313, r=-0.300, r=$ 0.039 and $r=-0.021$ respectively and a significantly negative correlation with BOD as $r=-0.600$. The BOD value in the study area decreases with increasing the $\mathrm{pH}$ of water which means that at alkaline condition microorganisms consumed less DO of water. The highest value of $\mathrm{pH}$ was recorded at Location 1 (Porabari) in April and the lowest was recorded at Location 2 (Katuli) in May. In March, values were more or less similar at all the sites. Islam et al. [5] found $\mathrm{pH}$ value between $5.0-6.4,7.42-7.6$ and $5.4-5.9$ respectively in premonsoon, monsoon and post-monsoon seasons at different stations in Dhaleshwari river. Islam et al. [15] found that the $\mathrm{pH}$ of the Shitalakkhya river varied from 6.9 to 8.0. Real et al. [6] found the $\mathrm{pH}$ of water as slightly alkaline in nature and ranged between 7.25 in June and 8.45 in April at three different stations of the same river namely Belta, Kendua and Charabari under the Porabari union of Tangail Sadar Upazilla. The standard value of $\mathrm{pH}$ is $6.0-8.5$ for aquatic life
[16] indicating that all the measured values in the present study were within standard limit.

\subsubsection{Dissolved Oxygen (DO)}

DO is a water quality parameter which predicts about a healthy aquatic life. A decreased DO level means that water environment is not suitable for aquatic biota. In the study, DO value varied from 4.11 to $7.31 \mathrm{mgL}^{-1}$ that may support healthy aquatic life and shows insignificant negative correlations $(\mathrm{p}<0.01)$ with temperature, $\mathrm{pH}$ and BOD as $\mathrm{r}=$ $0.423, r=-0.300$ and $r=-0.041$ and a significantly negative correlation with EC and TDS as $r=-0.586$ and $r=-0.590$ respectively. With increasing EC and TDS value, DO value decreases probably due to the increase of ionic constituent as well as organic matter in the water body.

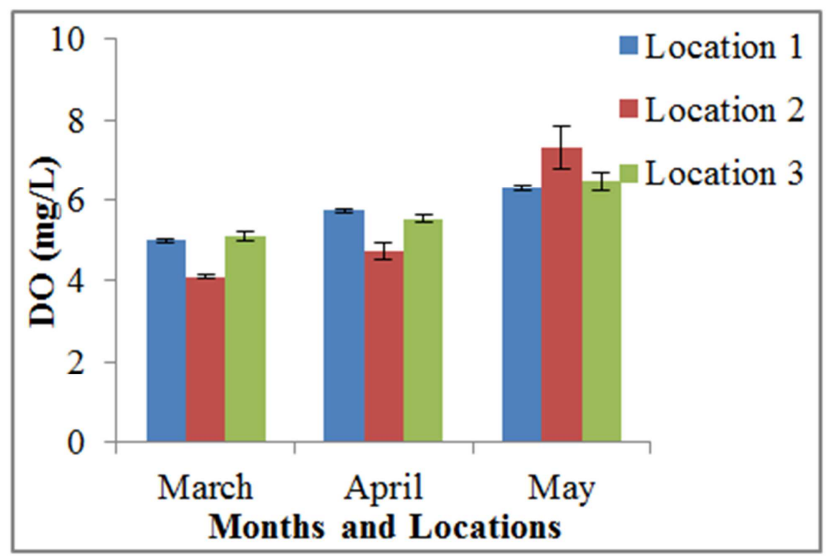

Figure 4. DO with three months and locations.

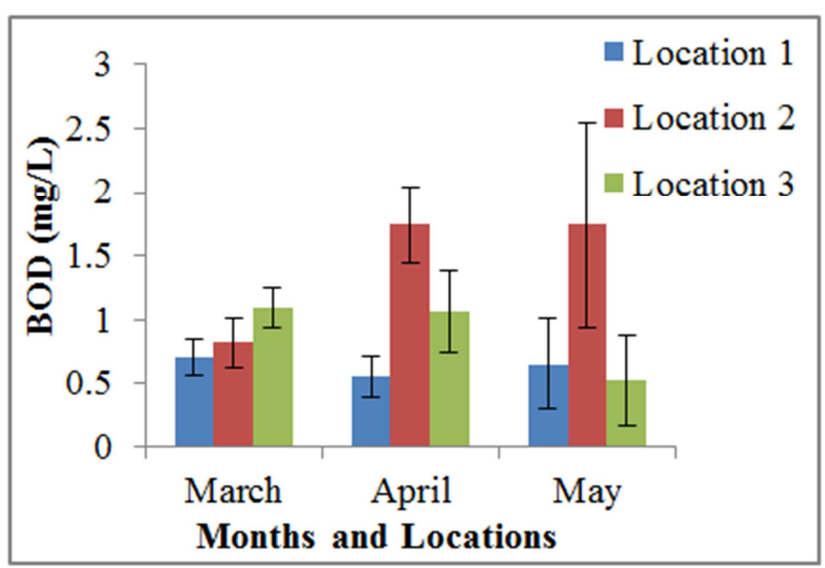

Figure 5. BOD with three months and locations.

The highest and lowest DO value both was recorded at Location 2 (Katuli) in May and March respectively. DO values of three locations were comparatively high in May than in March and April. Islam et al. [5] recorded DO ranged from 5.7 to $7.3,4.9$ to 9.0 and 4.1 to 9.8 and $\mathrm{mgL}^{-1}$ respectively in pre-monsoon, monsoon and post-monsoon seasons and the samples were collected between 9:30-11:30 am. Islam et al. [15] found that the DO of the Shitalakkhya river varied from 0.5 to $3.5 \mathrm{mgL}^{-1}$. Real et al. [6] found the monthly maximum mean DO value in April and the 
minimum mean in May which is ranged between $2.9-5 \mathrm{mgL}^{-1}$ and the samples were collected in the morning between 7.30 - 8.30 am during the month of April, May and June. They explained that the main causes of lower DO value in their study were due to the presence of organic matter in the water body, lack of sunlight in the morning (7.30-8.30 am), nutrients from induced fertilizers, human activities and other animal wastes.

\subsubsection{Biochemical Oxygen Demand (BOD)}

BOD gives idea about the presence of biologically active organism in the water body. As we found in the present study, BOD ranges from 0.50 to $1.74 \mathrm{mgL}^{-1}$ indicating no organic pollution in the water samples and shows significant negative correlations $(\mathrm{p}<0.01)$ with $\mathrm{pH}$ as $\mathrm{r}=-0.600$ and insignificant negative correlations with temperature, DO, EC and TDS as $r$ $=-0.149, \mathrm{r}=-0.041, \mathrm{r}=-0.097$ and $\mathrm{r}=-0.108$ respectively. The presence of microorganism in the water body decreases the DO level of water as the oxygen available in the water is being consumed by the microorganism [17] which creates a demands of oxygen in water making BOD value higher and in such case, fish and other aquatic organisms may not survive in the water due to insufficiency of DO. When water body contains relatively less amount of microorganism, less amount of oxygen will be consumed by them and consequently the BOD value will be lower and the DO level will be higher [1]. The highest value of BOD was recorded at Location 2 (Katuli) in April and the lowest was recorded at Location 3 (Mahmudnagar) in May. BOD values of three locations were too low which indicates no significant organic contaminants in the river. Real et al. [6] found mean concentrations of BOD as $0.87 \pm 0.19,1.12 \pm 0.6$ and $0.97 \pm$ $0.67 \mathrm{mgL}^{-1}$ in April, May and June respectively. Islam et al. [5] also recorded a lower BOD values during three seasons in the Dhaleshwari river which is suitable for fisheries production.

\subsubsection{Electrical Conductivity (EC)}

EC indicates the presence of overall ionic species in the water body. It is found to vary from 127 to $487 \mu \mathrm{Scm}^{-1}$ indicating low conductivity and shows strongly positive correlations $(p<0.01)$ with TDS as $r=0.998$. This means that the EC value increased with increasing the TDS concentration and is due to the fact that water sample with high value of TDS contains more ionic constituents which contributes to increase the EC value. The EC of the water samples also shows an insignificant positive correlations with temperature as $r=0.420$ and significant negative correlations with DO as $\mathrm{r}=-0.586$ while an insignificant negative correlations with $\mathrm{pH}$ and BOD as $\mathrm{r}=-0.039$ and $\mathrm{r}=-0.097$ respectively. The highest value of $\mathrm{EC}$ was recorded at Location 3 (Mahmudnagar) in March and the lowest was recorded at Location 2 (Katuli) and 3 (Porabari) in May. EC values of three locations were far below the standard value (Table-3). Islam et al. [5] recorded EC of the Dhaleshwari river water ranged as 288 to 411,136 to 267 and 181 to 540 $\mu \mathrm{Scm}^{-1}$ in pre-monsoon, monsoon and post-monsoon season, respectively. All sites showed lower EC values than the standard of $700 \mu \mathrm{Scm}^{-1}$ according to DoE (Department of Environment) [18] due to seasonal variations. Islam et al. [15] found that the EC of the Shitalakkhya river varied from 121 to $1167 \mu \mathrm{Scm}^{-1}$ which is higher than the standard value.

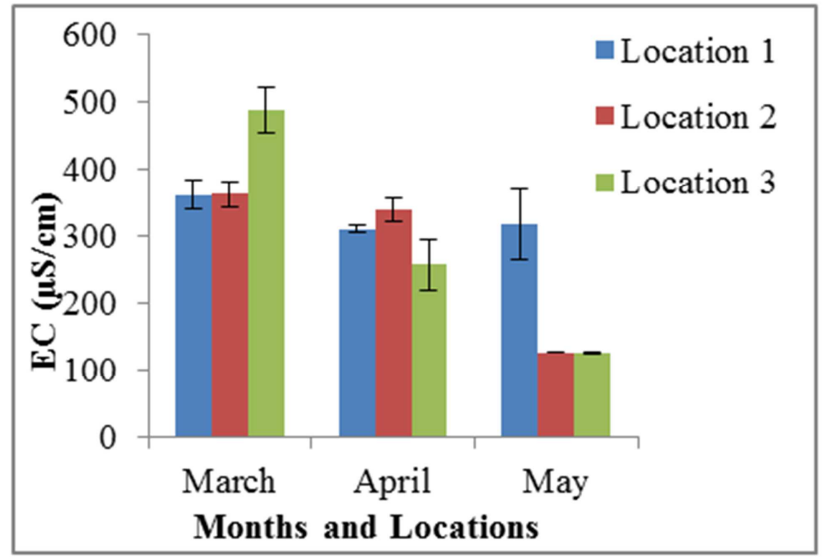

Figure 6. EC with three months and locations.

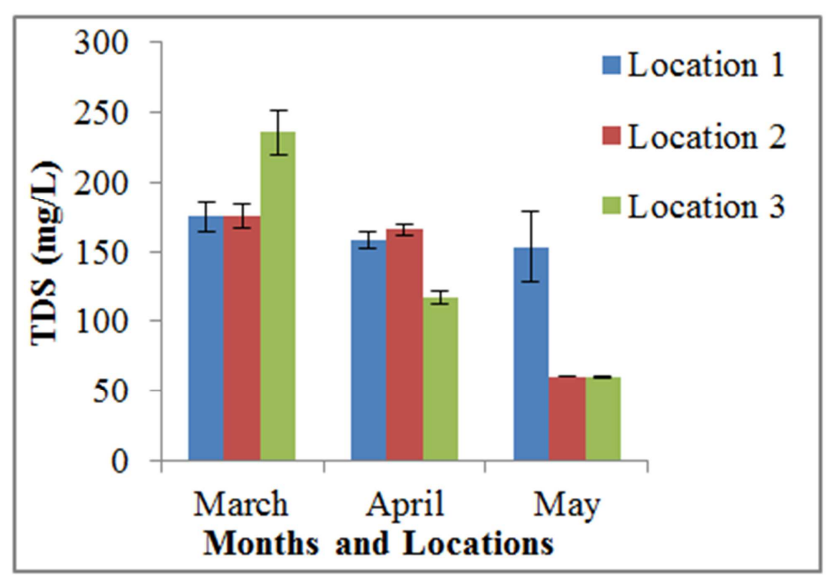

Figure 7. TDS in three months and locations.

\subsubsection{Total Dissolved Solids (TDS)}

TDS measures the amount of total dissolved material in water. A high value of TDS in the water body makes the water turbid. TDS in the study varied from 60 to $235 \mathrm{mgL}^{-1}$ that gives water with low concentration level of minerals and shows significantly positive correlations $(p<0.01)$ with EC as $r=0.998$ which is very much consistent. The TDS of the water samples also shows an insignificant positive correlations with temperature as $r=0.385$ and significant negative correlations with DO as $\mathrm{r}=-0.590$ while an insignificant negative correlations with $\mathrm{pH}$ and BOD as $\mathrm{r}=$ 0.021 and $r=-0.108$ respectively. The higher value of EC and TDS will reduce the DO value due to more ionic species in the water body. The highest value of TDS was recorded at Location 3 (Mahmudnagar) in March and the lowest was recorded at Location 2 (Katuli) and 3 (Mahmudnagar) in May. TDS values of three locations were far below the standard value (Table-3). Islam et al. [5] found the TDS values in the Dhaleshwari river water ranged as 190 to 224 , 69 to 131 and 95 to $299 \mathrm{mgL}^{-1}$ in pre-monsoon, monsoon and 
post-monsoon season, respectively. Islam et al. [15] found that the TDS of the Shitalakkhya river varied from 80 to 754 $\mathrm{mgL}^{-1}$ which is slightly higher than the standard value according to BSTI [19] and WHO [20] and lower than that of standard value according to ECR [21].

\subsection{Anions}

Anion concentrations in the Dhaleshwari river water during the months from March to May, 2016 are tabulated in Table 6 which shows that there is no change in the concentrations of $\mathrm{F}^{-}, \mathrm{Br}^{-}$and $\mathrm{NO}_{2}^{-}$ions during the study period and their concentration levels in water were below the detection limit indicating no significant contamination in the river. However, the concentrations of $\mathrm{Cl}^{-}, \mathrm{NO}_{3}{ }^{-}, \mathrm{SO}_{4}{ }^{2-}$ and $\mathrm{PO}_{4}{ }^{3-}$ ions were observable, although their concentration levels were also below the standard values except for $\mathrm{NO}_{3}{ }^{-}$ ion at Location 2 (Katuli) in the month of March. Descriptive statistics and Pearson's correlation matrix for $\mathrm{Cl}^{-}, \mathrm{NO}_{3}{ }^{-}, \mathrm{SO}_{4}{ }^{2-}$ and $\mathrm{PO}_{4}^{3-}$ ions in the Dhaleshwari river water during the study period are shown in Table 7 and 8 respectively. Correlation for $\mathrm{F}^{-}, \mathrm{Br}^{-}$and $\mathrm{NO}_{2}^{-}$cannot be computed because at least one of the variables is constant. The $\mathrm{F}^{-}, \mathrm{Br}^{-}$and $\mathrm{NO}_{2}^{-}$ ions do not correlate with themselves and with other ions as their concentrations are insignificant.

Table 6. Mean values of anions $\left(m g L^{-1}\right)$ at three selected locations of the Dhaleshwari river during March to May, 2016 with measurement uncertainty ( \pm ) $(k=2)$.

\begin{tabular}{|c|c|c|c|c|c|c|c|c|}
\hline Locations & Months & $\mathbf{F}^{-}$ & $\mathrm{Cl}^{-}$ & $\mathrm{Br}^{-}$ & $\mathrm{NO}_{2}^{-}$ & $\mathrm{NO}_{3}{ }^{-}$ & $\mathrm{SO}_{4}{ }^{2-}$ & $\mathrm{PO}_{4}{ }^{3-}$ \\
\hline \multirow{3}{*}{$\begin{array}{l}\text { Porabari } \\
\text { (Location 1) }\end{array}$} & March & $<0.5$ & $2.19 \pm 0.37$ & $<1.0$ & $<1.0$ & $2.94 \pm 0.49$ & $7.11 \pm 1.38$ & $3.71 \pm 0.67$ \\
\hline & April & $<0.5$ & $1.74 \pm 0.30$ & $<1.0$ & $<1.0$ & $1.79 \pm 0.30$ & $8.25 \pm 1.60$ & $4.44 \pm 0.80$ \\
\hline & May & $<0.5$ & $6.80 \pm 1.16$ & $<1.0$ & $<1.0$ & $1.00 \pm 0.17$ & $4.00 \pm 0.78$ & $2.31 \pm 0.42$ \\
\hline \multirow{3}{*}{$\begin{array}{l}\text { Katuli } \\
\text { (Location 2) }\end{array}$} & March & $<0.5$ & $1.30 \pm 0.22$ & $<1.0$ & $<1.0$ & $19.7 \pm 3.26$ & $8.08 \pm 1.57$ & $2.63 \pm 0.47$ \\
\hline & April & $<0.5$ & $5.20 \pm 0.89$ & $<1.0$ & $<1.0$ & $3.55 \pm 0.59$ & $9.37 \pm 1.82$ & $3.51 \pm 0.63$ \\
\hline & May & $<0.5$ & $2.31 \pm 0.40$ & $<1.0$ & $<1.0$ & $0.82 \pm 0.14$ & $3.69 \pm 0.72$ & $1.74 \pm 0.31$ \\
\hline \multirow{2}{*}{$\begin{array}{l}\text { Mahmudnagar } \\
\text { (Location 3) }\end{array}$} & March & $<0.5$ & $4.09 \pm 0.37$ & $<1.0$ & $<1.0$ & $1.04 \pm 0.17$ & $4.63 \pm 0.90$ & $3.53 \pm 0.64$ \\
\hline & May & $<0.5$ & $1.08 \pm 0.18$ & $<1.0$ & $<1.0$ & $0.51 \pm 0.08$ & $3.34 \pm 0.65$ & $2.05 \pm 0.37$ \\
\hline \multirow{3}{*}{ Standard value } & BSTI & 1.0 & 250 & - & Nil & 4.5 & - & - \\
\hline & WHO & 1.5 & 250 & - & 3.0 & 50 & 250 & - \\
\hline & ECR & 1.0 & $150-600$ & - & $<1.0$ & 10 & 400 & 6.0 \\
\hline
\end{tabular}

Table 7. Descriptive statistics of the anions $\left(\mathrm{Cl}, \mathrm{NO}_{3}{ }^{-}, \mathrm{SO}_{4}{ }^{2-}\right.$ and $\left.\mathrm{PO}_{4}{ }^{3-}\right)$ of water samples of the Dhaleswari river.

\begin{tabular}{llllllll}
\hline Parameters & N & Range & Min. & Max. & Sum & Mean & SD \\
\hline $\mathrm{Cl}^{-}$ & 9 & 5.72 & 1.08 & 6.80 & 27.89 & 3.0989 & 1.92707 \\
$\mathrm{NO}_{3}{ }^{-}$ & 9 & 19.2 & 0.51 & 19.7 & 33.10 & 3.6778 & 6.07710 \\
$\mathrm{SO}_{4}{ }^{2-}$ & 9 & 6.03 & 3.34 & 9.37 & 53.67 & 5.9633 & 2.26093 \\
$\mathrm{PO}_{4}{ }^{3-}$ & 9 & 2.70 & 1.74 & 4.44 & 26.92 & 2.9911 & 0.88184 \\
\hline
\end{tabular}

${ }^{* *}$ Min. $=$ Minimum, Max. $=$ Maximum, $\mathrm{SD}=$ Standard Deviation.

Table 8. Pearson's Correlation matrix among the anions $\left(\mathrm{Cl}, \mathrm{NO}_{3}^{-}, \mathrm{SO}_{4}^{2-}\right.$ and $\mathrm{PO}_{4}{ }^{3-}$ ) of water samples of the Dhaleswari river.

\begin{tabular}{lllll}
\hline Parameters & $\mathrm{Cl}^{-}$ & $\mathbf{N O}_{3}{ }^{-}$ & $\mathbf{S O}_{4}{ }^{2-}$ & $\mathbf{P O}_{4}{ }^{3-}$ \\
\hline $\mathrm{Cl}^{-}$ & 1 & -0.318 & -0.068 & 0.001 \\
$\mathrm{NO}_{3}{ }^{-}$ & -0.318 & 1 & 0.484 & -0.050 \\
$\mathrm{SO}_{4}{ }^{2-}$ & -0.068 & 0.484 & 1 & $0.694^{*}$ \\
$\mathrm{PO}_{4}{ }^{3-}$ & 0.001 & -0.050 & $0.694^{*}$ & 1 \\
\hline
\end{tabular}

*. Correlation is significant at the 0.05 level (2-tailed).

\subsubsection{Chloride Ion (CI)}

The concentration of $\mathrm{Cl}^{-}$in the Dhaleshwari river water is in the range: 1.08 to $6.80 \mathrm{mgL}^{-1}$ which lie in the permissible limit and shows an insignificant negative correlation $(\mathrm{P}<0.05)$ with $\mathrm{NO}_{3}{ }^{-}$and $\mathrm{SO}_{4}{ }^{2-}$ as $\mathrm{r}=-0.318$ and $\mathrm{r}=-0.068$ respectively and insignificant positive correlation with $\mathrm{PO}_{4}{ }^{3-}$ as $\mathrm{r}=0.001$. Islam et al. [22] found the $\mathrm{Cl}^{-}$concentration in Rupsha river water of Khulna region, Bangladesh, ranged as: 444-724 $\mathrm{mgL}^{-1}$ and argued that the water of the Rupsha river in their study area is highly polluted. The lower concentration of $\mathrm{Cl}^{-}$in the present study indicates that there is no chlorinated pesticide pollution in the Dhaleshwari river water which may be found due to the addition of pesticides in the surrounding agricultural lands of the river.

\subsubsection{Nitrate Ion $\left(\mathrm{NO}_{3}^{-}\right)$}

The $\mathrm{NO}_{3}^{-}$concentration in the river water were found bellow the limit of detection except the water sample of Location 2 (Katuli) that was measured in the month of March which is higher than the permissible level by BSTI $\left(4.5 \mathrm{mgL}^{-1}\right)$ and WHO $\left(10 \mathrm{mgL}^{-1}\right)$ probably due to the excessive use of nitrate fertilizer or others agricultural practices in the surrounding agricultural lands and due to considerable surface runoff from agricultural fields to the river water. Besides, $\mathrm{NO}_{3}{ }^{-}$ion shows an insignificant negative correlation $(\mathrm{P}<0.05)$ with $\mathrm{Cl}^{-}$and $\mathrm{PO}_{4}{ }^{3-}$ as $\mathrm{r}=-0.318$ and $\mathrm{r}=-0.050$ respectively and insignificant positive correlation with $\mathrm{SO}_{4}{ }^{2-}$ as $\mathrm{r}=0.484$. Real et al. [6] found that the nitrate concentration in Dhaleshwari river water varied from 0.51 $\mathrm{mgL}^{-1}$ in June to $3.66 \mathrm{mgL}^{-1}$ in April with the mean value of $2.55 \pm 1.35 \mathrm{mgL}^{-1}$ in April, $2.38 \pm 1.02 \mathrm{mgL}^{-1}$ in May and $0.78 \pm 0.25 \mathrm{mgL}^{-1}$ in June. Thus, in the present study, except the Location 2 (Katuli), nitrate concentrations of the Dhaleshwari river water were within the permissible limit (10.0 $\left.\mathrm{mgL}^{-1}\right)$ throughout the study period according to DoE, Bangladesh [18].

\subsubsection{Sulphate Ion $\left(\mathrm{SO}_{4}{ }^{2-}\right)$}

The maximum concentration of $\mathrm{SO}_{4}{ }^{2-}$ in the Dhaleshwari river water was found $9.37 \mathrm{mgL}^{-1}$. The water in the month of March and April were contaminated slightly by $\mathrm{SO}_{4}{ }^{2-}$ ion while in the month of May concentration were below the limit of detection for all three locations and shows an insignificant 
negative correlation $(\mathrm{P}<0.05)$ with $\mathrm{Cl}^{-}$as $\mathrm{r}=-0.068$ and an insignificant positive correlation with $\mathrm{NO}_{3}{ }^{-}$as $\mathrm{r}=0.484$. But shows strongly positive correlation with $\mathrm{PO}_{4}{ }^{3-}$ as $\mathrm{r}=0.694$. Real et al. [6] measured the mean sulphate concentrations at different months of Dhaleshwari river water as $6.61 \pm 1.78$ $\mathrm{mgL}^{-1}, 7.61 \pm 2.16 \mathrm{mgL}^{-1}$ and $3.68 \pm 0.23 \mathrm{mgL}^{-1}$ respectively. Sulphate concentrations in the study found very low compared to the permissible limit $\left(22 \mathrm{mgL}^{-1}\right)$ by DoE [18].

\subsubsection{Phosphate Ion $\left(\mathrm{PO}_{4}^{3-}\right)$}

The concentration of $\mathrm{PO}_{4}{ }^{3-}$ in the Dhaleshwari river water found in the range of 1.74 to $4.44 \mathrm{mgL}^{-1}$ which lie within the permissible limit by ECR [19] and shows an insignificant negative correlation $(\mathrm{P}<0.05)$ with $\mathrm{NO}_{3}{ }^{-}$as $\mathrm{r}=-0.050$ and an insignificant positive correlation with $\mathrm{Cl}^{-}$as $\mathrm{r}=0.001$ and significant positive correlation with $\mathrm{SO}_{4}{ }^{2-}$ as $\mathrm{r}=0.694$. Real et al. [6] found phosphate concentration varied from 1.74 $\mathrm{mgL}^{-1}$ (lowest) in June to $4.4 \mathrm{mgL}^{-1}$ (highest) in May with the monthly mean concentrations recorded as $3.29 \pm 0.58 \mathrm{mgL}^{-1}$, $3.64 \pm 0.71 \mathrm{mgL}^{-1}$ and $2.03 \pm 0.28 \mathrm{mgL}^{-1}$ in April, May and June respectively which are in very close agreement with results obtained in the present study.

\subsection{Heavy Metals Concentration in Water Samples}

Heavy metals concentration of water from three selected locations of the Dhaleshwari river in the months from March to May, 2016 as tabulated in Table 9 shows that there is no change in the concentrations during the whole study period and the concentration levels of all the heavy metals in water of the river were far below the permissible limit except for arsenic (As) in the month of April at Katuli (Location 2) and in March and April at Mahmudnagar (Location 3) in which the values were slightly greater than the permission level by WHO $\left(0.01 \mathrm{mgL}^{-1}\right)$ [20] but below the acceptable limit by BSTI [19] and ECR [21] (0.05 $\left.\mathrm{mgL}^{-1}\right)$ indicating no significant heavy metal pollution in the Dhaleshwari river water. The very low concentration of heavy metals in water may be attributed to the fact that the river water is always flowing and metals cannot be accumulated in one place in the flowing water.

Islam et al. [15] found the concentration of $\mathrm{Cr}$ and $\mathrm{Cd}$ in the Shitalakkhya river water in the range of 0.0371 to 0.1023 $\mathrm{mgL}^{-1}$ and 0.0065 to $0.0152 \mathrm{mgL}^{-1}$ respectively. Islam et al. [22] studied the heavy metal concentration in water of the Rupsha river of Khulna region, Bangladesh and found the concentration of $\mathrm{Pb}, \mathrm{Cd}$ and $\mathrm{Cr}$ ranged as: $<0.10-0.15 \mathrm{mgL}^{-1}$, $<0.001 \mathrm{mgL}^{-1}$ and $<0.005-4.33 \mathrm{mgL}^{-1}$ respectively. $\mathrm{Pb}$ and $\mathrm{Cr}$ concentrations in the Rupsha river water were found in the level higher than the standard value and makes water unusable. However, $\mathrm{Cd}$ contents in all the samples ranged within the acceptable limits. Islam et al. [5] found $\mathrm{Cd}$ concentrations in the Dhaleshwari river water higher than the standard level $0.005 \mathrm{mgL}^{-1}$ according to ECR [21] and claimed that the phosphoric fertilizers in the agricultural soils and paints and dyes for cloth manufacturing along the river are the most ubiquitous source of excessive $\mathrm{Cd}$ contamination in the studied river water. In this respect, the Dhaleshwari river was polluted in terms of $\mathrm{Cd}$ concentrations. The variations of heavy metal concentrations in the Dhaleshwari river water along with the present study were mainly due to different collection spots and seasons.

Table 9. Mean values of heavy metals $\left(\mathrm{mgL}^{-1}\right)$ in water samples at three selected locations of the Dhaleshwari river during March to May 2016 with measurement uncertainty $( \pm)(k=2)$.

\begin{tabular}{|c|c|c|c|c|c|c|}
\hline Locations & Months & $\mathbf{P b}$ & Cd & $\mathrm{Cr}$ & $\mathrm{Hg}$ & As \\
\hline \multirow{3}{*}{$\begin{array}{l}\text { Porabari } \\
\text { (Location 1) }\end{array}$} & March & $<0.01$ & $<0.001$ & $<0.005$ & $<0.001$ & $0.004 \pm 0.001$ \\
\hline & April & $<0.01$ & $<0.001$ & $<0.005$ & $<0.001$ & $0.003 \pm 0.001$ \\
\hline & May & $<0.01$ & $<0.001$ & $<0.005$ & $<0.001$ & $0.008 \pm 0.001$ \\
\hline \multirow{3}{*}{$\begin{array}{l}\text { Katuli } \\
\text { (Location 2) }\end{array}$} & March & $<0.01$ & $<0.001$ & $<0.005$ & $<0.001$ & $0.003 \pm 0.001$ \\
\hline & April & $<0.01$ & $<0.001$ & $<0.005$ & $<0.001$ & $0.012 \pm 0.002$ \\
\hline & May & $<0.01$ & $<0.001$ & $<0.005$ & $<0.001$ & $0.002 \pm 0.000$ \\
\hline \multirow{2}{*}{$\begin{array}{l}\text { Mahmudnagar } \\
\text { (Location 3) }\end{array}$} & March & $<0.01$ & $<0.001$ & $<0.005$ & $<0.001$ & $0.015 \pm 0.002$ \\
\hline & May & $<0.01$ & $<0.001$ & $<0.005$ & $<0.001$ & $0.002 \pm 0.000$ \\
\hline \multirow{3}{*}{ Standard value } & BSTI & 0.05 & 0.005 & 0.05 & 0.001 & 0.05 \\
\hline & WHO & 0.05 & 0.005 & 0.05 & 0.001 & 0.01 \\
\hline & ECR & 0.05 & 0.005 & 0.05 & 0.001 & 0.05 \\
\hline
\end{tabular}

Overall, the present study shows there is almost no significant pollution in Dhaleshwari river which is consistent with the similar study carried out by Islam et al. [5] and there is no significant change in the water quality from 2012 to 2016 with respect to the studied parameters. The possible reason for these findings may be that the study area have no any kind of industries till now and only pollution sources are agrochemicals from surroundings lands which also contributes very less to the pollutions of the study area. Another reason is the heavy rain even in the pre-summer monsoon (March to May) along with the summer monsoon
(June to September) which sometimes causes flash flood in the study area. However, from the microbial study conducted by Real et al. [6], it is suggested that the water of the Dhaleshwari river is polluted and is not suitable for human activities. Islam et al. [5] and Real et al. [6] carried out their study from the same river (Dhaleshwari) with the present study, but their sampling sites were entirely different and the studies were not performed at the same time of the year which may be another important reason for the variations of the results among the studies. 


\section{Conclusion}

Pollutants from various sources enter into the river system mainly either by direct discharges or surface runoff from the agricultural, industrial and municipal pollutant sources. The study was aimed to evaluate the present status of Dhaleshwari river water quality in terms of physicochemical parameters, anions and major heavy metals. Analysis of physicochemical parameters such as temperature, $\mathrm{pH}, \mathrm{DO}$, BOD, EC, TDS shows that the levels of pollution in Dhaleshwari river are beyond the threshold limits. According to the statistical analysis, temperature, EC and TDS show positive correlations $(\mathrm{p}<0.01)$ with each other and negative correlations with $\mathrm{pH}, \mathrm{DO}$ and BOD which themselves show negative correlations with each other. Concentrations of anions were also found below the recommended values except in the month of March for Location 2 (Katuli) in which $\mathrm{NO}_{3}^{-}$ion concentration $\left(19.7 \mathrm{mgL}^{-1}\right)$ is found higher than the permissible level by WHO $\left(10 \mathrm{mgL}^{-1}\right)$. This may be due to the considerable surface runoff of excessively used nitrate fertilizer in the surrounding agricultural lands into the river water. Statistically, the $\mathrm{Cl}^{-}$ion shows positive correlations $(\mathrm{p}<0.05)$ with $\mathrm{PO}_{4}{ }^{3-}$ ion and negative correlations with $\mathrm{NO}_{3}{ }^{-}$and $\mathrm{SO}_{4}{ }^{2-}$ ions. The $\mathrm{NO}_{3}{ }^{-}$ion shows positive and negative correlations with $\mathrm{SO}_{4}{ }^{2-}$ and $\mathrm{PO}_{4}{ }^{3-}$ ions respectively while $\mathrm{SO}_{4}{ }^{2-}$ and $\mathrm{PO}_{4}{ }^{3-}$ ion shows positive correlations with each other. The concentration of heavy metals in Dhaleshwari river water were also beyond the standard recommended values. The examined physicochemical parameters, anions and heavy metals contaminations indicate that the quality of Dhaleshwari river water is almost suitable for aquatic lives and human consumption and the water in the study area is also suitable for utilizing in irrigation, fishing, household, livestock, industrial and recreational purposes. However from microbial study, it was suggested by Real et al. [6] that the water of the river is not suitable for human activities. In this regard, future study on microbial load of water body, fish species, sediments, phytoplankton, zooplankton, microalgae etc. should be carried out for a longer period of time to get a more clear idea about the water quality and aquatic environment of the Dhaleshwari river.

\section{Acknowledgements}

The authors received no specific funding for this research work from elsewhere and the work is not also supported by or under any projects. However, we are grateful to the authority of Institute of National Analytical Research and Service (INARS), Bangladesh Council of Scientific and Industrial Research (BCSIR), Dhaka, Bangladesh for providing laboratory facilities and others logistic supports during research period.

\section{Author's Contributions}

Md. Y. Mia designed the experiment. Md. A. B. Siddique, S. Akter and M. A. Munni carried out the sample preparation and analysis. Md. A. B. Siddique wrote the manuscript with data interpretation and Md. A. Ahsan and Md. A. Akbor revised the manuscript critically for important intellectual content. All authors read and approved the final manuscript.

\section{Competing Interests}

The authors declare that they have no competing interests.

\section{References}

[1] Hafizur RM, Nuralam HM, Rumainul IM. Investigation of physicochemical parameter, heavy metal in Turag river water and adjacent industrial effluent in Bangladesh, Journal of Science, Technology and Environment Informatics, 2017; 5(1):347-360.

[2] Mustafa MG, Brooks ACA. Comparative study of two seasonal flood plain aquaculture systems in Bangladesh, Water Policy, 2009; 11:69-79.

[3] Ahmad MK, Islam S, Rahman S, Haque MR, Islam MM. Heavy Metals in Water, Sediment and Some Fishes of Buriganga River, Bangladesh. Int. J. Environ. Res., 2010; 4:321-332.

[4] Majumder RC. History of Ancient Bengal, Tulsi Prokashani, Kolkata, 1971; 3-4.

[5] Islam MS, Meghla NT, Suravi, Mamun SA, Islam M. Status of water quality in the Dhaleshwari River and its effect on aquatic organism, Journal of Environmental Science and Water Resources, 2012; 1:192-201.

[6] Real KH, Khanam N, Mia MY, Nasreen M. Assessment of Water Quality and Microbial Load of Dhaleshwari River Tangail, Bangladesh. Advances in Microbiology, 2017; 7:523533 .

[7] Banglapedia. The National Encyclopedia of Bangladesh, Asiatic Society of Bangladesh, Dhaka, Bangladesh. 2014.

[8] BBS (Bangladesh Bureau of Statistics). District Statistics 2011 Tangail, Ministry of Planning, Government of People's Republic of Bangladesh, Bangladesh. 2013.

[9] Brammer H. Land Use and Land Use Planning in Bangladesh, University Press Limited, Dhaka, Bangladesh. 2002.

[10] APHA (American Public Health Association), Standard Methods for the Examination of Water and Wastewater, American Water Works Association, Water Environment Federation, USA, $22^{\text {nd }}$ edition, 2012; p 1-30 \& 40-175.

[11] APHA (American Public Health Association), Standard Methods for the Examination of Water and Wastewater, American Water Works Association, Water Environment Federation, USA, $22^{\text {nd }}$ edition, 1998.

[12] Davis JC. Statistical and Data Analysis in Geology, Wiley, New York, $2^{\text {nd }}$ edition, 1986; p 646.

[13] Mandal HS, Das A, Nanda AK. Study of some physicochemical water quality Parameters of Karola River, West Bengal-an attempt to estimate pollution status, Int. J. Environ. Prot., 2012; 2:16-22. 
[14] Patil PN, Sawant DV, Deshmukh RN. Physicochemical parameters for testing of water -a review, Int. J. Environ. Sci., 2012; 3:1194-1207.

[15] Islam JB, Sarkar M, Rahman AKML, Ahmed KS. Quantitative assessment of toxicity in the Shitalakkhya River, Bangladesh, Egypt. J. Aquat. Res., 2015; 41:25-30.

[16] Das B. Fisheries Resources Management in Bangladesh. Bangla Academy, Dhaka, Bangladesh, 1997; 153-155.

[17] Sawyer CN, McCarty PL, Parkin GF. Chemistry for Environmental Engineering and Science, McGraw-Hill, New York, 5th edition, 2003.

[18] DoE (Department of Environment), Environmental Quality Standard for Bangladesh, Ministry of Environment and Forest, Dhaka, Bangladesh. 1997.
[19] BSTI (Bangladesh Standards and Testing Institute), BDS1240, 2001.

[20] WHO (World Health Organization), Guidelines for Drinking water Quality, 1984; p 51.

[21] ECR (The Environment Conservation Rules), Ministry of Environment and Forest, Government of the People's Republic of Bangladesh, Bangladesh. 1997.

[22] Islam MS, Mohanta SC, Siddique MAB, Al-Mamun MA, Hossain N, Bithi UH. Physico-chemical assessment of water quality parameters in Rupsha river of Khulna region, Bangladesh, The International Journal of Engineering and Science (IJES), 2018; 7:73-78. 